\title{
Ocular herpes simplex virus infections: reduced sensitivity to acyclovir in primary disease
}

\author{
S J Charles, J J Gray
}

\begin{abstract}
Forty isolates of herpes simplex virus (HSV) obtained from ocular herpetic infections were assayed for their sensitivity to five antiviral agents. There were wide ranges of sensitivity to foscarnet, idoxuridine, and vidarabine, but the majority were sensitive to acyclovir and ganciclovir. Reduced sensitivity to acyclovir was seen in four isolates, all of which were from primary infections acquired in the community and without a previous history of treatment with antiviral drugs.
\end{abstract}

With the widespread use of antiviral drugs in herpetic infections the development of resistant herpes simplex virus (HSV) strains must be monitored. In-vitro virus resistance to acyclovir (ACV) may be selected for by passage in cell culture in the presence of the drug. ${ }^{12}$ Resistant strains arise from alterations at one or both of the gene loci coding for virus-specific enzymes thymidine kinase (TK) and DNA polymerase (DNA-pol) and may emerge during treatment with ACV. ${ }^{3}$

In a recent study of all HSV isolates in this hospital ${ }^{4}$ it was noted that isolates obtained from ocular infections had a reduced sensitivity to ACV compared with infections at other sites.

The present study aimed to evaluate the sensitivity of HSV isolates to a range of antiviral drugs, including ACV, in the entire population of patients presenting to the Ophthalmology Clinic with herpetic eye disease, together with isolates from ocular infections sent to the virology laboratory from general practitioners. The active concentrations of antiviral drugs at the site of ocular infections are not well known, and so antiviral resistance should be considered relative to sensitive strains. It seems reasonable to consider that isolates showing a greater than 10-fold increase in the inhibitory concentration of the drug above the mean value for sensitive isolates may be significant in terms of reduced effectiveness of therapy. ${ }^{5}$

Addenbrooke's Hospital, Cambridge, Department of Ophthalmology S J Charles

\section{Clinical Microbiology} and Public Health Laboratory

J J Gray

Correspondence to:

J J Gray, Clinical Microbiology and Public Health Laboratory, Addenbrooke's Hospital Cambridge CB2 2QQ.

Accepted for publication 30 November 1989

\section{Materials and methods}

\section{PATIENTS}

A total of 40 isolates of $\mathrm{HSV}$ were obtained from 35 patients with ocular infections. These included 30 consecutive patients seen with herpetic eye disease in the Ophthalmology Clinic over a 12-month period from July 1988 and isolates sent from general practitioner clinics over the same period (five patients). Virus was isolated from two patients during consecutive episodes of infection and from more than one site in three patients during the same episode.
VIRUS ISOLATION

Swabs were collected in virus transport medium ( $2 \mathrm{ml}$ Hanks's buffered saline with $1 \%$ bovine albumin) from lesions of patients with suspected HSV infection of the eye. A volume of $100 \mu \mathrm{l}$ was inoculated into cultures of human amnion, HEp2, and MRC-5 cells, which were then rolled for 21 days at $37^{\circ} \mathrm{C}$. Cultures showing a cytopathic effect characteristic of HSV were stored at $-20^{\circ} \mathrm{C}$. Serotyping of the $\mathrm{HSV}$ isolates was performed by direct immunofluorescence (Boots-Celltech Diagnostics Ltd.).

\section{CONTROLS}

Isolates of HSV designated DM 21 (a TKdeletion mutant), TP 2.5 (a DNA-pol mutant), and R9C2 (a TK and DNA-pol mutant), all resistant to $\mathrm{ACV}$, were grown in cultures of human amnion cells for use as controls, as was a strain, sensitive to ACV, designated SC16.

\section{ANTIVIRAL AGENTS}

Five agents all reported to be active against HSV were used: acyclovir, ${ }^{6}$ ganciclovir, ${ }^{7}$ foscarnet, ${ }^{8}$ idoxuridine, ${ }^{9}$ and vidarabine. ${ }^{10}$

\section{DYE UPTAKE TEST}

Virus growing in cultures of cells reduces the uptake of the vital stain neutral red by the cells. When the assay is performed in microtitre plates, the dye can be eluted and its concentration measured colorimetrically." Isolates of virus were screened for susceptibility to concentrations of each antiviral agent from $0.05 \mu \mathrm{g} / \mathrm{ml}$ to $100 \mu \mathrm{g} / \mathrm{ml}$. They were thawed and diluted 1 in 10 and 1 in 100 in a suspension of vero cells $(100000$ cells/ml) in growth medium (BSS 199, 5\% FBS). $100 \mu \mathrm{l}$ of each dilution was placed in alternate rows on the microtitre plate and an equal volume of antiviral drug, at varying concentrations, was then added to each well. Cell controls and virus controls were included with each isolate, and the plates were incubated at $37^{\circ} \mathrm{C}$ in an atmosphere of $5 \%$ carbon dioxide for three days.

After incubation the medium was aspirated from the wells and replaced with $50 \mu \mathrm{l}$ of the vital stain neutral red $(0.15 \%$ in phosphate buffered saline (PBS) at $\mathrm{pH} 6 \cdot 5)$. The plates were then incubated for one hour at $37^{\circ} \mathrm{C}$, after which the stain was removed by aspiration and the wells washed twice with PBS pH 6.5. The dye was rendered soluble by addition of $100 \mu \mathrm{l}$ phosphate ethanol buffer (PBS pH 4.5 containing $10 \%$ ethanol). The optical density was read at $510 \mathrm{~nm}$. End points were taken as the lowest concentration of antiviral agent to inhibit growth of the virus by $50 \%\left(\mathrm{IC}_{50}\right)$ when compared with 
TABLE I Principal presenting signs of patients with ocular infections from whom $H S V$ was isolated

\begin{tabular}{lc}
\hline Principal ocular sign & Number $(n=35)$ \\
\hline Dendritic ulcer & 13 \\
Other corneal epithelial disease & 5 \\
Perforated corneal ulcer & 1 \\
Conjunctivitis & 8 \\
Blepharitis & 8 \\
\hline
\end{tabular}

control wells containing virus dilutions and cells only.

\section{Results}

CLINICAL SPECTRUM

The spectrum of herpetic eye disease seen is shown in Table I. The most common presenting sign was dendritic ulceration, seen in $37 \%$ cases.

All isolates were HSV type 1. Twenty-one cases were suffering from a first clinical herpetic infection, nine cases were recurrent herpetic eye disease, and five had a past history of herpes labialis. Only five patients had previously been treated with ACV.

\section{VIRAL SENSITIVITIES}

Idoxuridine. There was a wide distribution of $\mathrm{IC}_{50}$ from $<0.05 \mu \mathrm{g} / \mathrm{ml}$ to $100 \mu \mathrm{g} / \mathrm{ml}$, mean $28.35 \mu \mathrm{g} / \mathrm{ml}$ (Fig 1).

Vidarabine. $\mathrm{IC}_{50}$ ranged from $<0.50 \mu \mathrm{g} / \mathrm{ml}$ to $100 \mu \mathrm{g} / \mathrm{ml}$, mean $18.36 \mu \mathrm{g} / \mathrm{ml}$.

Foscarnet. $\quad \mathrm{IC}_{50}$ ranged from $<0.50 \mu \mathrm{g} /$ $\mathrm{ml}$ to $100 \mu \mathrm{g} / \mathrm{ml}$, mean $21.57 \mu \mathrm{g} / \mathrm{ml}$.

Acyclovir. The majority of isolates (35 out of 40 ) were sensitive to ACV $(<0.05 \mu \mathrm{g} / \mathrm{ml})$, though three had significantly reduced sensitivity and one, with an $\mathrm{IC}_{50}$ of $10 \mu \mathrm{g} / \mathrm{ml}$, was resistant to ACV (Fig 2). The clinical background of these four isolates will be discussed. The mean $\mathrm{IC}_{50}$ was $0.33 \mu \mathrm{g} / \mathrm{ml}$, but after excluding the isolate with $\mathrm{IC}_{50}$ of $10.00 \mu \mathrm{g} / \mathrm{ml}$ this was $0.08 \mu \mathrm{g} / \mathrm{ml}$.

Ganciclovir. The majority of isolates were sensitive $\left(\mathrm{IC}_{50}<0.05 \mu \mathrm{g} / \mathrm{ml}\right.$ ), though the isolate found to be resistant to ACV was also resistant $\left(\mathrm{IC}_{50} 10.00 \mu \mathrm{g} / \mathrm{ml}\right)$. The mean $\mathrm{IC}_{50}$ to ganci-

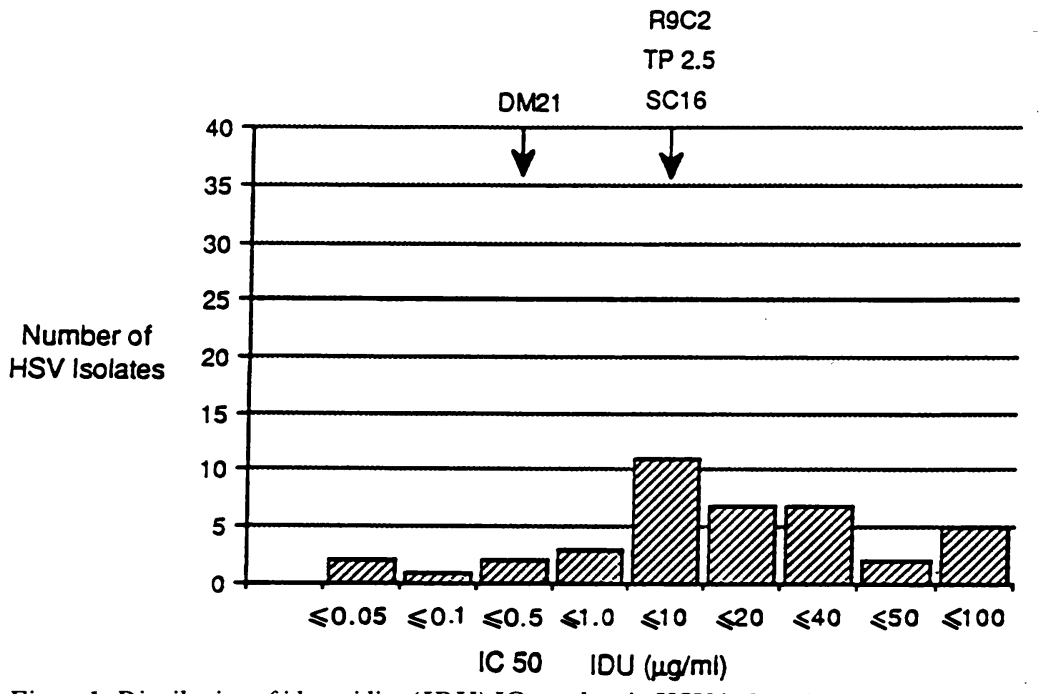

Figure 1: Distribution of idoxuridine (IDU) IC $C_{50}$ values in $H S V$ isolates in patients with ocular infection. IC 50 values for control strains (see text) are also shown. clovir was $0.32 \mu \mathrm{g} / \mathrm{ml}(0.025 \mu \mathrm{g} / \mathrm{ml}$ after excluding the isolates with $\mathrm{IC}_{50} 10.00 \mu \mathrm{g} / \mathrm{ml}$ ).

\section{Discussion}

This study, using a dye uptake assay, has shown that the majority of HSV isolates from patients with herpetic eye disease are particularly sensitive in vitro to ACV. A total of $87.5 \%$ of isolates were sensitive to $\mathrm{ACV}$ with $\mathrm{IC}_{50}$ of less than $0.05 \mu \mathrm{g} / \mathrm{ml}$. Isolates were also sensitive to ganciclovir in a similar distribution, as would be expected from its similar mode of action, ${ }^{6}$ but there was a wider distribution of sensitivities to the other antiviral agents. A total of three out of $40(7 \cdot 5 \%)$ isolates had reduced sensitivity to ACV and one out of $40(2.5 \%)$ was resistant.

It might be expected that resistant isolates would be seen in patients with a previous history of treatment with ACV. However, the isolate with an $\mathrm{IC}_{50}$ of $10.00 \mu \mathrm{g} / \mathrm{ml} \mathrm{ACV}$ was obtained from a 12-year-old asthmatic boy suffering from a primary attack of HSV blepharitis at the time of a hospital admission with pneumonia. No causative organism for the pneumonia was isolated, and he responded to intravenous antibiotics. $\mathrm{He}$ was not known to have been in contact with active HSV infection, though his father had had herpes labialis many years previously (and had never received ACV). This may indicate that resistant strains of HSV exist in the general population, though we cannot exclude the possibility that a resistant strain was selected during virus isolation. This resistant strain was sensitive to IDU, foscarnet, and vidarabine.

Of the three isolates with significantly reduced ACV sensitivities $\left(\mathrm{IC}_{50} 0.5 \mu \mathrm{g} / \mathrm{ml}\right)$ none had any history of recurrent HSV infection or previous treatment with ACV. One was a case of follicular conjunctivitis associated with a first attack of herpes labialis and the other two were first dendritic ulcers. All resolved on treatment but one recurred. The isolate recovered from the recurrent infection was sensitive to $\mathrm{ACV}$ ( $\mathrm{IC}_{50}$ $<0.05 \mu \mathrm{g} / \mathrm{ml}$ ). The sensitive strain may have established the latent infection before the resistant strain emerged or was more able to establish a latent infection, as has been previously described. ${ }^{12}$

It is difficult to assess the clinical importance of infection with strains of HSV showing altered sensitivity to ACV when the drug is applied topically. After topical administration concentrations of ACV measured in tears varied from $0.07 \mu \mathrm{g} / \mathrm{ml}$ to $465 \mu \mathrm{g} / \mathrm{ml},{ }^{13}$ and in aqueous was around $1.7 \mu \mathrm{g} / \mathrm{ml} .{ }^{14}$ Thus it seems that drug concentrations sufficient to inhibit the virus are available at the site of infection even though the strain may have a significantly reduced sensitivity to ACV. The strain resistant to ACV and ganciclovir was sensitive to foscarnet, IDU, and vidarabine, so that a therapeutic alternative, if required, is available.

It thus seems that strains of HSV with reduced sensitivity to ACV exist in the population of patients with herpetic eye disease, but, because of the high ACV levels achieved when applied topically, they respond well to therapy. Virus from subsequent recurrences of HSV disease in such cases may be fully sensitive to ACV. 


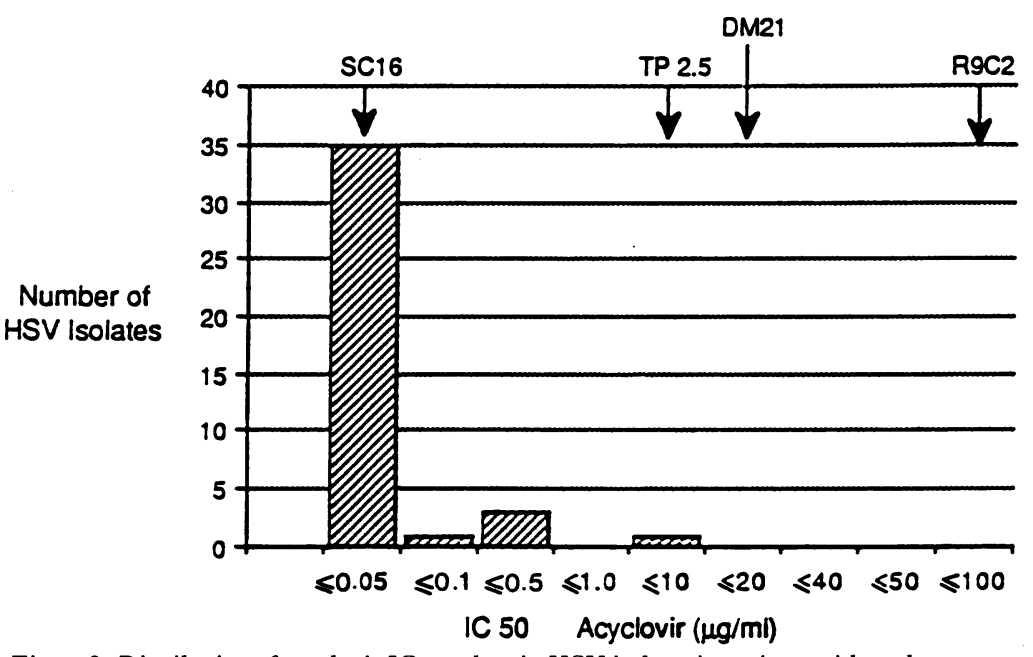

Figure 2: Distribution of acyclovir $I C_{50}$ values in $H S V$ isolates in patients with ocular infection. IC 50 values for control strains (see text) are also shown.

1 Field HJ, Darby G, Wildy P. Isolation and characterization of acyclovir-resistant mutants of herpes simplex virus. $\mathcal{F}$ Gen Virol 1980; 49: 115-24.

2 Schnipper LE, Crumpacker CS. Resistance of herpes simplex virus to acycloguanosine: role of the viral thymidine kinase and DNA polymerase loci. Proc Natl Acad Sci USA 1980; 77: 2270-3.

3 Burns WH, Saral R, Santos GW, et al. Isolation and character- isation of resistant herpes simplex virus after acyclovir therapy. Lancet 1982; i: 421-3.

4 Gray JJ, Wreghitt TG, Baglin T. Susceptibility to acyclovir of herpes simplex virus: emergence of resistance in patients with lymphoid and myeloid neoplasia. F Infect 1989; 19: $31-40$.

5 Field $\mathrm{HJ}$. A perspective on resistance to acyclovir in herpes simplex virus. $\mathcal{F}$ Antimicrob Chemother 1983; 12 (suppl B): $129-35$

6 Schaeffer HJ, Beauchamp C, de Miranda P, Elion GB, Braver DJ, Collins P. 9-(2-hydroxyethoxymethyl) guanine activity against viruses of the herpes group. Nature 1978; 272: 583-5.

7 Cheng YC Grill SP, Dutschman GE, Nakayama K, Ba KF. Metabolism of 9-(1-dihydroxy-2-propoxymethyl) guanine, a new anti-herpes virus compound, in herpes simplex virus-infected cells. 7 Biol Chem 1983; 258: 12460-4.

8 Oberg B. Antiviral effects of phosphoformate. Pharmacol Ther 1989; 40: 213-85.

9 Prusoff WH. Idoxuridine or how it all began. In: De Clercq E, ed. Clinical use of antiviral drugs. Boston: Nijhoff, 1988: 15-24.

10 Miller FA, Dixon GJ, Ehrlich J, Sloan BJ, McLean IW. Antiviral activity of 9-beta-D-arabinofuranosyladenine. Cell culture studies. Antimicrob Agents Chemother 1968; 8: $136-47$

11 McLaren C, Ellis MN, Hunter GA. A colorimetric assay for the measurement of the sensitivity of herpes simplex virus to antiviral agents. Antiviral Res $1983 ; 3: 323-4$.

12 Price RW, Khan A. Resistance of peripheral autonomic neurons to in vivo productive infection by herpes simplex virus mutants deficient in thymidine kinase. Infect Immun 1981; 34: 571-80.

13 Collum LMT, McGettrick P, Akhtar J, Lavin J, Rees PJ. Oral acyclovir (Zovirax) in herpes simplex dendritic corneal acyclovir (Zovirax) in herpes simplex dendritic corneal

14 Porrier RH, Kingham JD, de Miranda P, Annel M. Intraocular antiviral penetration. Arch Ophthalmol 1982; 100: 1964-7. 